\title{
Litter Fall in A Primary and Two Logged-over Lowland Tropical Rainforests in Pasirmayang, Jambi.
}

\author{
UPIK ROSALINA WASRIN* and AGUS EKA PUTERA ** \\ 'Senior Scientist and "Research Assistant, Remote Sensing and Ecology Laboratory, \\ SEAMED BIOTROP, P.O. Box 116, Bogor 16001, Indonesia
}

\begin{abstract}
Litter accumulation in a primary and a logged-over lowland dipterocarp forest at Pasirmayang, Jambi was measured using the litter trap method. In the primary forest, traps were placed in four distinct areas, reflecting the succession stages of the forest from building to maturation. In the logged-over forest, litter production was measured at two different sites, one cut in 1979/1980 and the second in 1983/1984.

In the primary forest, average litter production during the observation period was $925 \mathrm{~g} \mathrm{~m}^{\prime \prime 2} \mathrm{yr}^{\prime}$. In the logged-over forest, average litter production was $721 \mathrm{~g} \mathrm{~m}^{\prime 2} \mathrm{yr}^{1}$ for the site cut in 1979/1980 and 706 $\mathrm{g} \mathrm{m}^{\prime 2} \mathrm{yr}^{1}$ for the site cut in 1983/1984. Leaves comprised the major contributor of litter with $67 \%$ of total litter produced in the primary forest, 67\% of total litter in the 1979/1980 cut logged-over forest, and 65\% of total litter in the 1983/1984 cut logged-over forest.

The purpose of the study was to use litter fall as a measure of forest productivity to assess the recovery of logged-over forests and, to provide a basis for comparison of forest-derived land practices for appropriate forest management strategies.
\end{abstract}

Key words: Litter production/primary forest/logged-over forest/forest productivity/Pasirmayang/Jambi.

\section{INTRODUCTION}

Knowledge of forest productivity is a basic requirement for determining appropriate management strategies for forests, to maintain or even increase productivity. Forest productivity is based on the capture of solar energy and soil-derived nutrients to form chemical compounds used to synthesize various compounds for plant growth and reproduction (Binkley 1986). Therefore, litter fall can be used as an indicator of productivity (Medwecka-Kornas 1970). Forest productivity is influenced by a range of factors such as nutrient status of the ecosystem, organic matter decomposition, nutrient cycle in the plant (biochemical), nutrient cycle in the ecosystem (biogeochemical), and nutrient cycle between ecosystems (geochemical), which are very complex, since it is also influenced by climate and the availability of nutrients from parent rocks.

\footnotetext{
Present Address :

* Lecturer, Faculty of forestry, Bogor Agricultural University, Campus Darmaga, Bogor, Indonesia email : wasrinsy@ indo.net.id "

** Staff, Bali Barat National park, Bali, Indonesia
} 
twigs, bark, flowers, and fruit or seed (small to fine litter), and branches and fallen stems (big litter) to a lesser extent (Medwecka-Kornas 1970).

Litter fall can be measured by using litter traps in the form of a basket, box or funnel (Medwecka-Kornas 1967; Newbould 1967; Korcagin 1960). For tropical forests, Kira \& Schidei (1967) suggested to use baskets with a circular diameter of $50 \mathrm{~cm}$ (Medwecka-Kornas 1970). The frequency of litter collection from the trap depends on the phenology and the method used. Nevertheless, measurement of litter production should represent a minimum period of one year of the total growth season, and should be monitored continuously over several years for at least 3 years (Medwecka-Kornas 1970).

Although there is hardly any primary lowland forest left in Sumatera, we aimed at collecting litter fall data in one of the last remnants, to provide a basis of comparison for forest-derived land use practices. Selective cutting to harvest forest timber practiced up to recent days has resulted in a mostly degraded vegetation structure such as pioneer trees with low canopy (Dynamic /), a group of young trees with low canopy (Dynamic 2), trees with low branches and small crowns (Homeostatic 1 ), and if left undisturbed for sometime (10 years ), this yiejds tall trees with high branches and large crowns similar to the primary forest (Homeostatic 2). Based on the different vegetation structures following various logging practices and its impacts, we hypothesize that litter fall will differ in quantity and quality (plant components) among various gaps of successional stages of lowland forest, while the litter fall of old logged-over forests (10 years old) equals that of the primary forest.

\section{MATERIALS AND METHODS}

To measure litter production, 4 traps were made of nylon with a $1 \mathrm{~mm} \times 1$ $\mathrm{mm}$ mesh. The circular trap mouth has a diameter of 1 meter and is fixed by 3 iron pipes about $100 \mathrm{~cm}$ from the ground, and the lowest part of the trap located about 20 $\mathrm{cm}$ from the ground (Fig. 1). The circular form avoids the margin effect of the plot.

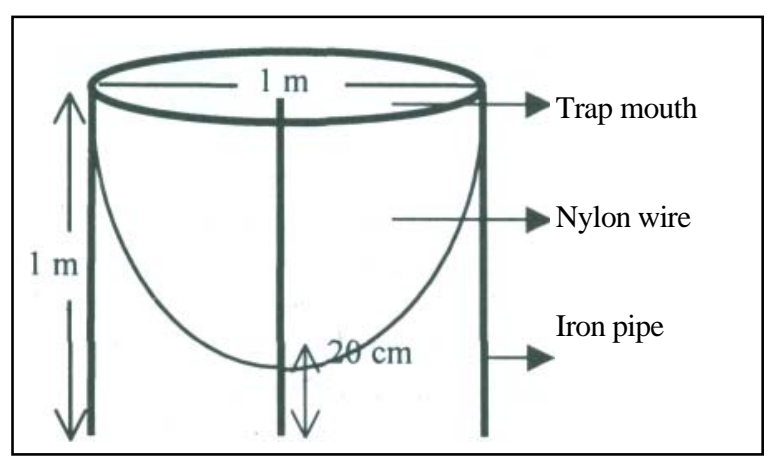

Figure 1. Illustration of the 
In the primary forest, measurement was conducted inside a 3 ha area $(100 \mathrm{~m}$ x $300 \mathrm{~m}$ ) which is divided into $20 \mathrm{~m}$ x $20 \mathrm{~m}$ plots, arranged systematically at 25 traps per hectare (Fig. 2)

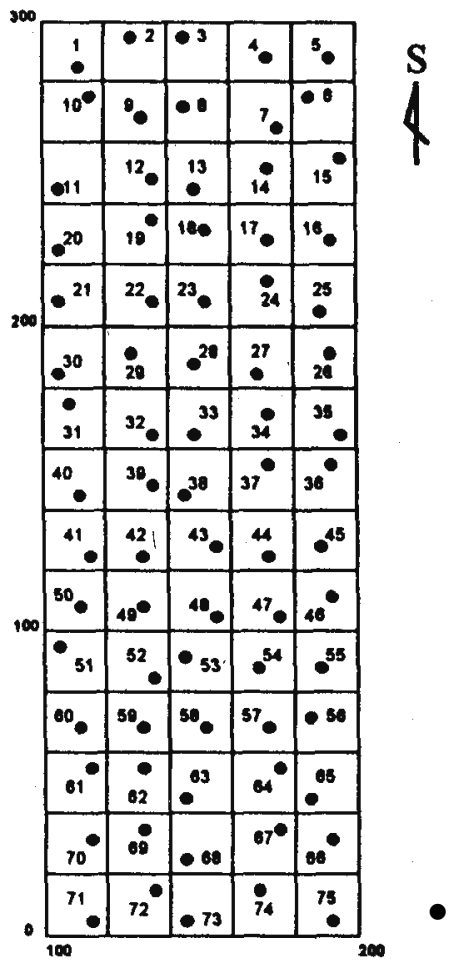

Fig. 2. Location of litter traps inside the 3 Ha plot of a primary forest

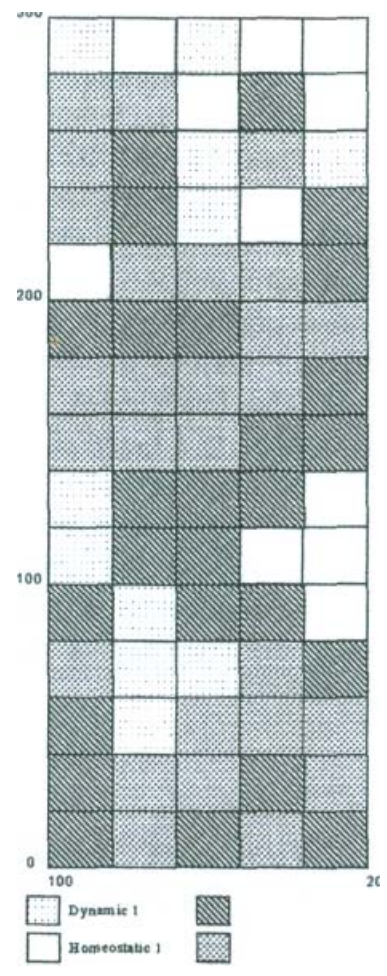

Fig. 3. Vegetation dynamics phases inside the litter production observation plot at a primary forest site after Laumonier (1997)

Arrangement of traps was based on the four vegetation dynamics phases used b Laumonier (1997) and defined as follows :

- Dynamic 1 : dominated by pioneer trees with very low canopy.

- Dynamic 2 : dominated by trees of the future with low canopy.

- Homeostatic 1 : dominated by trees of the present with low branches and small crowns.

- Homeostatic 2 : dominated by tall trees of the present with high branches and large crowns. 
In the logged-over forest, litter production was assessed in two different forest areas, one cut in 1979/1980 and the second in 1983/1984. The traps were systematically placed inside a square plot with distance between traps of about 50 $\mathrm{m}$. The total number of traps was 25 representing about a $200 \mathrm{~m} \mathrm{x} 200 \mathrm{~m}$ area (Fig. 4). It was assumed that the logged-over forest only had one vegetation dynamic phase.

Litter collection from traps was .carried out monthly. Collection from the primary forest began from August 1991 until November 1993 and was resumed during the period of June 1994 until July 1996. Collections from the 1979/1980 cut logged-over forest were made from July 1994 - July 1996, and from the 1983/1984 cut logged-over forest during March 1994 - July 1996.

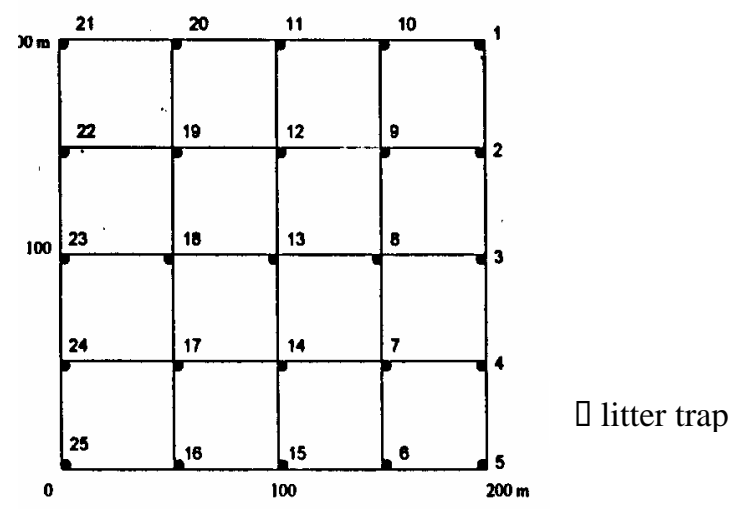

Figure 4. Location of litter traps inside a $200 \mathrm{~m} \mathrm{x}$ $200 \mathrm{~m}$ plot of a logged-over forest site.

Litter was classified as leaves, flowers, fruits, stipules, twigs, bark and others. Litter was oven-dried at a temperature of $105^{\circ} \mathrm{C}$ for 48 hours and dry weight was measured according to Wasrin et al. 1995.

\section{RESULTS AND DISCUSSION}

\section{A. Litter Production at the Primary Forest}

Measurement of litter production at the primary forest was conducted from August 1991 - November 1993 interrupted from October 1993 to May 1994, due to a technical problem. A total of 54 measurements were obtained that fluctuated during the observation period, as shown in Fig. 5. Litter production in gm $^{\prime 2}$ was obtained upon conversion of litter production in $g$ trap" ${ }^{1}$, by dividing the amount by 
trap size $\left(0.785 \mathrm{~m}^{2}\right)$. Litter production shown is the monthly average value collected from 75 traps.

The highest amount of litter production recorded was $169 \mathrm{gm}^{2}$ in October 1991. The smallest amount was $39.22 \mathrm{gm}^{\prime 2}$ in February 1996. Average litter production during the observation period was $77 \mathrm{gm}^{2} \sim^{2}$ month $\sim^{\prime}$ or $925 \mathrm{gm}^{2} \sim^{2}$ year $\sim^{\prime}$. This value is lower compared to the number given by Wanner in Jordan (1983) in the rain forest of north Borneo (1070 gnV² year') and those of Kira in Jordan (1983) in a tropical rainforest of Malaysia (1055 gnV ${ }^{2}$ year $\left.{ }^{\prime}\right)$, but higher compared to the rainforest in Java (810 gm"'2year $\left.{ }^{\prime}\right)$.

In general, leaves contributed the largest portion of monthly litter production with an average of $48 \mathrm{gm}^{\wedge} \mathrm{month}^{11}$ or $62 \%$ of total litter production, followed by twigs (22 \%), others (litter components that cannot be identified or classified further due to their small size) (6\%), bark (4\%), fruit (3\%), stipules (2\%), and flowers (1\%).

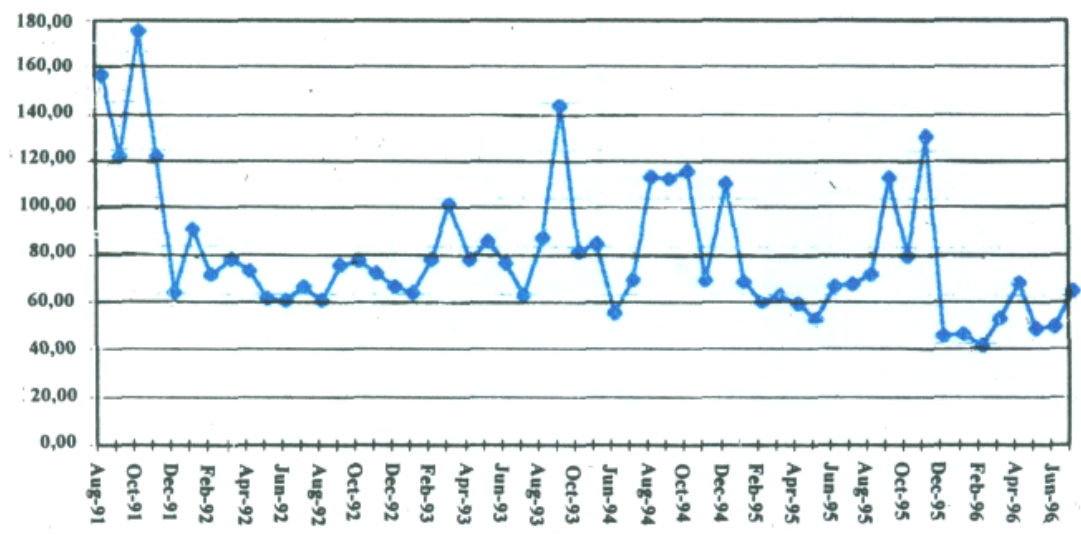

Figure 5. Total litter production per month (average of 75 traps) in the primary forest during 54 months of observation (August 1991 -July 1996)

Fig. 6, 7, and 8 show fluctuations in litter production attributed to specific plant parts over the observation period. Leaves significantly influence the results for total litter production as leaves comprise the major constituent. Thus, the high amounts attributed to leaves (Fig. 6) correspond to those recorded for total litter (Fig. 5) with highest values in August 1991, October 1991, September 1993, August through October 1994, and September 1995. Compared to rainfall levels at the study site (Fig. 9) there is a good correlation between high amounts of leaf litter and relatively low levels of rainfall. On the other hand, leaf litter decreased during months of high levels of rainfall. 
BIOTROPIA No. 14, 1999

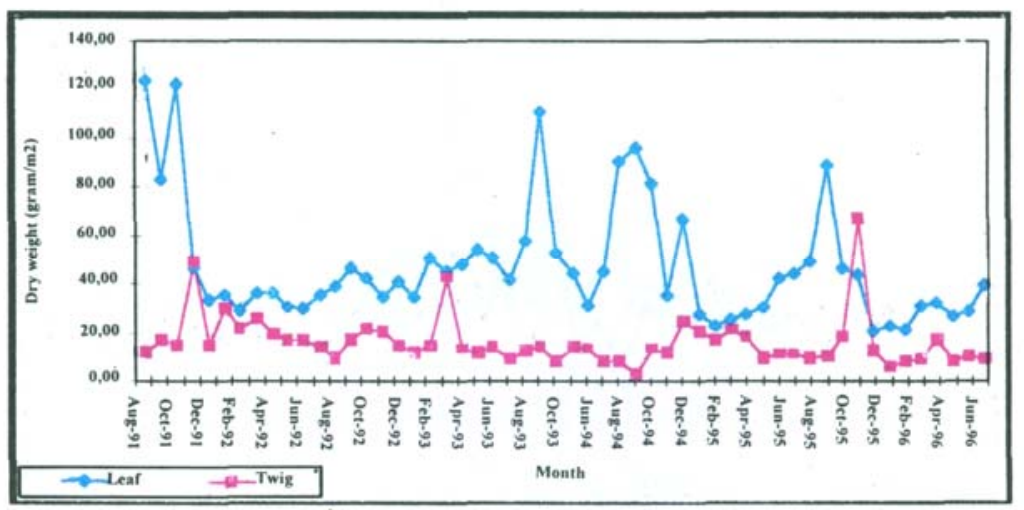

Figure 6 . Leaf and twig litter production during 54 months of obserbation in the primary forest site.

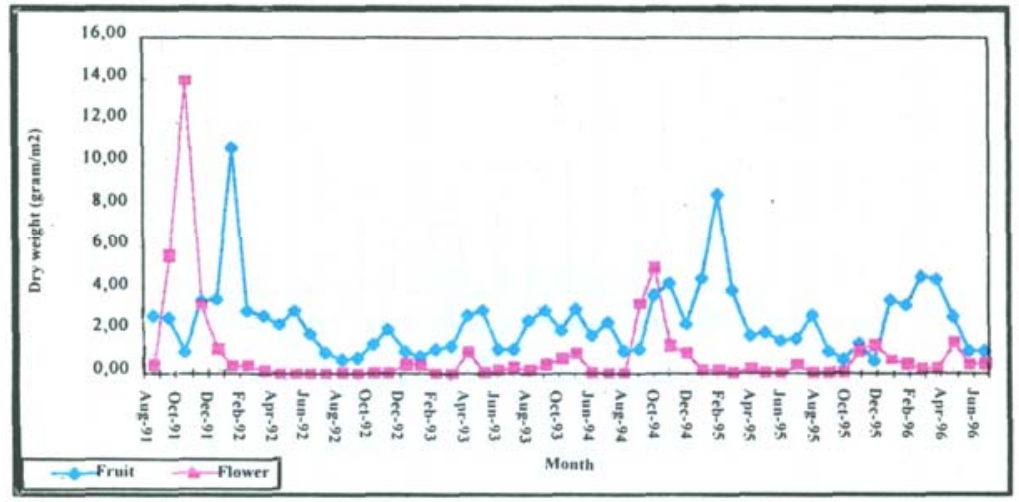

Figure. Fruit and flower litter production during of months of observation in the primary forest site. 


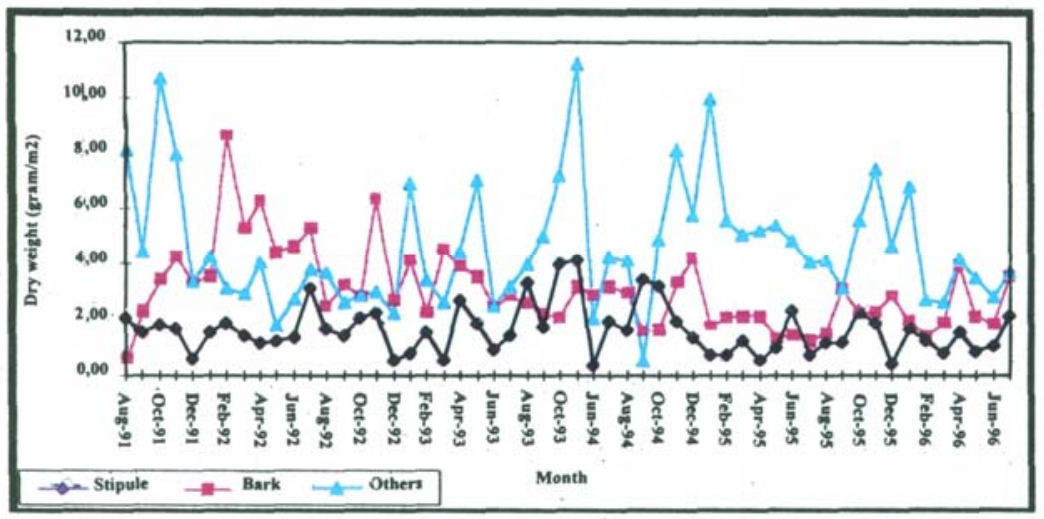

Figure 8. stipule, bark and other litter component production during 54 months of obserbation in the primary forest site

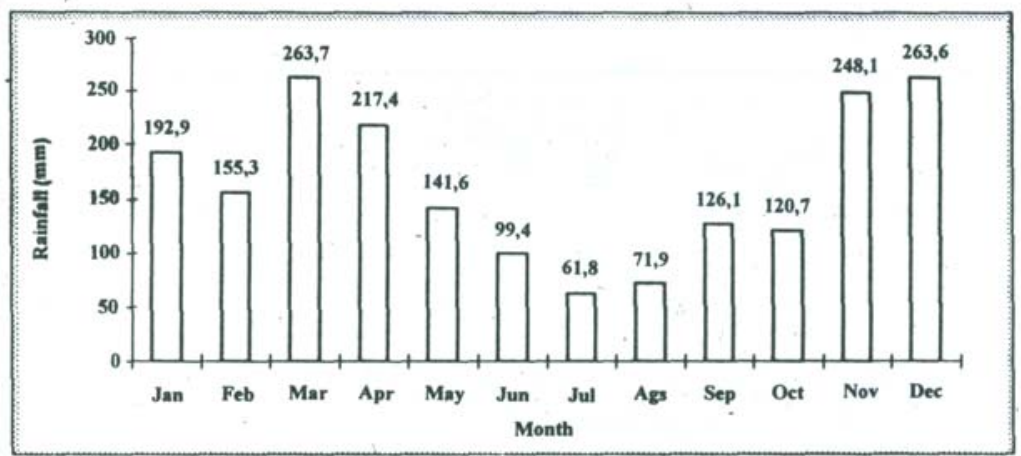

Figure 9. Average variability rainfall per month derived from monthly rainfall data between 1985 -1994.

Total litter production is also high, albeit less than half of the highest total value for January 1992, March 1993 and December 1994. This could be attributed to the increase in fruit litter in January 1992 and twigs litter in March 1993 and December 1994.

Fig. 7 compares litter attributed to flowers to that of fruit. The pattern of accumulation for each over time is relatively similar where periods of increased 
flower litter are followed by periods of increased fruit litter three months later as would be expected. For example, flower litter was high in October 1991 and October 1994 and fruit litter was optimal in January 1992 and February 1995. Similarly, a relatively high level of fruit litter occurred from January 1995 till April 1996, preceded by a moderate accumulation of flower litter in November and December 1995. Litter from other plant parts like twigs, stipules, and bark did not follow clear patterns of accumulation.

Fig. 10 compares litter production to the vegetation dynamics phases of a primary forest. The average monthly data of litter produced was obtained from 11 traps for the Dynamic 1 phase, 26 traps for the Dynamic 2 phase, 11 traps for the Homeostatic 1 phase, and 27 traps for the Homeostatic 2 phase (see Fig. $£$ and Fig. $3)$. In general, litter produced in the Homeostatic 2 phase was higher than that produced in the other phases, with a total amount of $68 \mathrm{gm}^{\prime 2}$ month"1 compared to 62 gm"'2month" for Homeostatic 1, 58 gm"' month"1 for Dynamic 2, and 53 gm"² month"' for Dynamic 1.

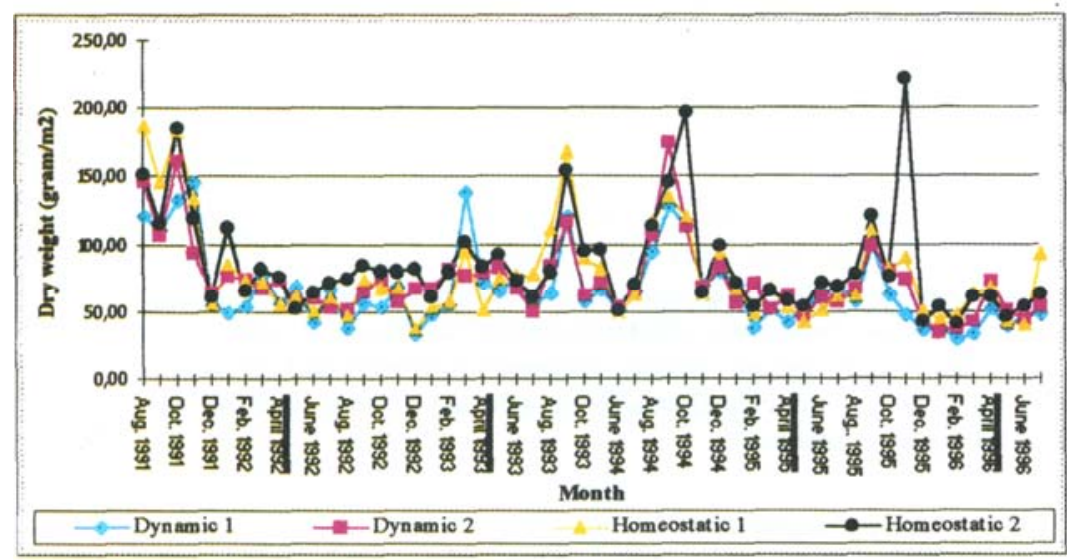

Figure 10. Litter fall in a primary forest based on vegetation dynamics phase.

To assess the relationship between litter production, the rate of litter decomposition, and the vegetation dynamics phases, the data were statistically analyzed using ANOVA (Setyawan 1999). The results indicated that the data for the four vegetation dynamics phases, the logged-over forest cut in 1979/1980, and the logged-over forest cut in 1983/1984 were significantly influenced by litter production. When the data for the vegetation dynamics phases of the primary forest are 
compared to data for the logged-over forests, the highest amount of litter was produced in the Homeostatic 2 phase, followed by the Homeostatic 1, Dynamic 2, and Dynamic 1 phases, the logged-over forest cut in 1979/1980, and the loggedover forest cut in 1983/1984 with the lowest amount (Setyawan 1999).

The results suggest that litter production increases with stability or maturity of the forest ecosystem, considering that the vegetation dynamics phases of the primary forest from Dynamic 1 to Homeostatic 2 reflect a succession process toward stability or maturity characterized by the increase in tree structure. Increased stability or maturity of a forest ecosystem results from the increase in forest structure, both horizontally (species distribution) and vertically (stratification). According to Ewel (1983) forest structure increases with maturity. This increase in forest structures characterized by an increase in tree crown density, species diversity, tree age, and biomass that influences increased litter production (Setyawan 1999). Odum in Jordan (1983) suggested that net production of litter increases as vegetation becomes larger and leaf area index goes up. Litter production is optimal during the climax vegetation stage, and changes in the course of the succession process. Litter production varies as it can be influenced by season, tree species, crown density, light, temperature variation during day and night, nutrient availability, disease, age of trees, and forest habitat size (Alrasjid 1986; Heald 1971). The lower value obtained for litter production in a logged-over forest compared to the primary forest, suggests that the logged-over forest structure is still in the building phase. This would mean that the logged-over forest structure is still unstable, and that its vegetation dynamics phase is more juvenile compared to the primary forest. The lower tree biomass resulting from the logging activity may also account for the lower value of litter production. Soerianegara in Setyawan (1999) suggested that logging activity might change the forest environment from climax to the unstable condition. In turn, this could affect tree growth. Ecologically, logging activity could reduce biodiversity and soil fertility, increase soil erosion and surface run-off, thus decreasing the environmental quality in general. Nutrient supplies decrease and forest stability is disturbed.

\section{B. Litter Fall in Logged-over Forest.}

The observation period for litter fall in a logged-over forest was shorter than in the primary forest, i.e. 29 months for the logged-over forest cut in 1983/1984 and 24 months for the logged-over forest cut in 1979/1980. Litter fall in the logged-over forest cut in 1979/1980 and 1983/1984 are 60 gnrtnonu $\mathrm{Y}^{1}$ or $721 \mathrm{gm}^{\wedge} \mathrm{year}^{1}$ and 59 gm"'month"' or 706 gm $^{2}{ }^{2}$ year $\sim$ ', respectively. If we compare litter production of the primary forest to that of the logged-over forest over the same observation period (Fig. 11), the logged-over forests show relatively small differences in litter fall compared to the primary forest. Litter fall amounts for the logged-over forest cut in 1979/1980 approach those for the primary forest, whereas litter fall levels for the logged-over forest cut in 1983/1984 are lower. This would suggest that the longer 
BIOTROPIA 14, 1999

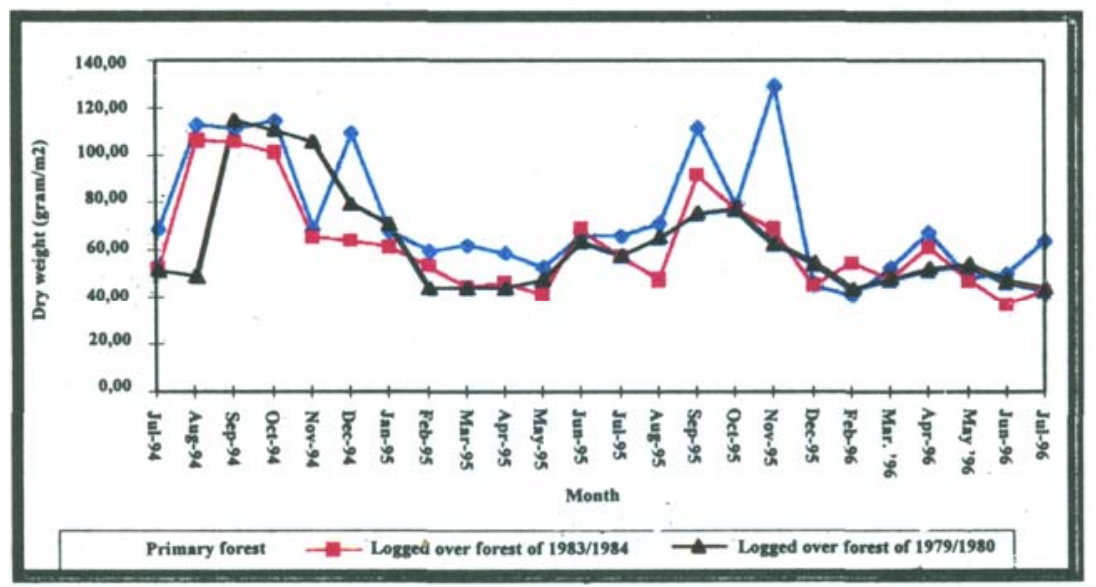

Figure 11. Litter fall of a primary forest and logged-over forest between July 1994-July 1996.

time period following logging activity allowed the logged-over forest to recover its ondition toward climax, and begins to resemble the primary forest.

The proportional distribution of litter components from the total in the loggediver forest cut in 1979/1980 and cut in 1983/1984 are presented in Figures 12 and

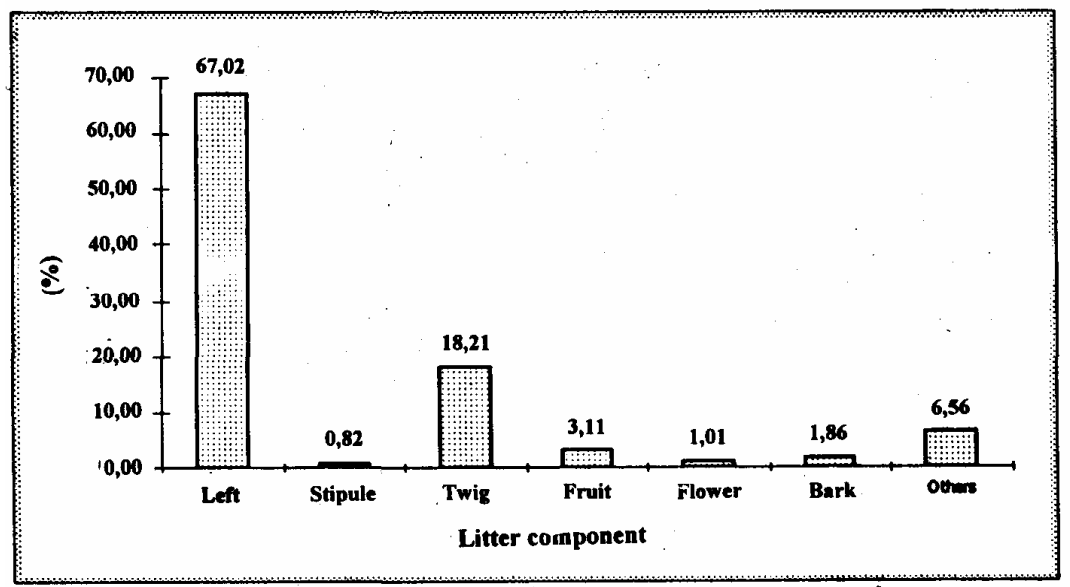

Figure 12. Percentage of litter component (average monthly dry weight) in a logged-over forest out in 1979/1980 
13. Like in the primary forest, leaves and twigs still comprise the major form of litter in the logged-over forest. However, the proportion of leaf litter to the other components in the logged-over forest is slightly higher than in the primary forest.

The dynamics of leaf litter production in the logged-over forest cut in 1979/1980 and cut in 1983/1984 are shown in Figures 14 and 15. In general, the highest production of leaf litter occurred in September - October, while the lowest amount was in February - April. This pattern was reflected in the total litter production,dynamics of both forest types (Figures 16 and 17) as leaf Ijtter yields the largest contribution to total litter produced. If we compare this with the average monthly rainfall data recorded between 1985 - 1994 (Fig. 9), highest leaf litter production coincides with months of relatively low rainfall or toward the end of the dry season, while the lowest levels occurred in months with relatively high rainfall.

This pattern is similar with that for the primary forest. This relates to the increase in availability of sun light in the dry season that increases photosynthetic activity. Photosynthesis produces carbohydrate as a source of biomass increase and maturation of leaves and other parts of the plant, thus contributing to the increase in litter weight.

The relation between flower and fruit litter production in the logged-over forest cut in 1979/1980 is not obvious from the data obtained. Fig. 18 shows that

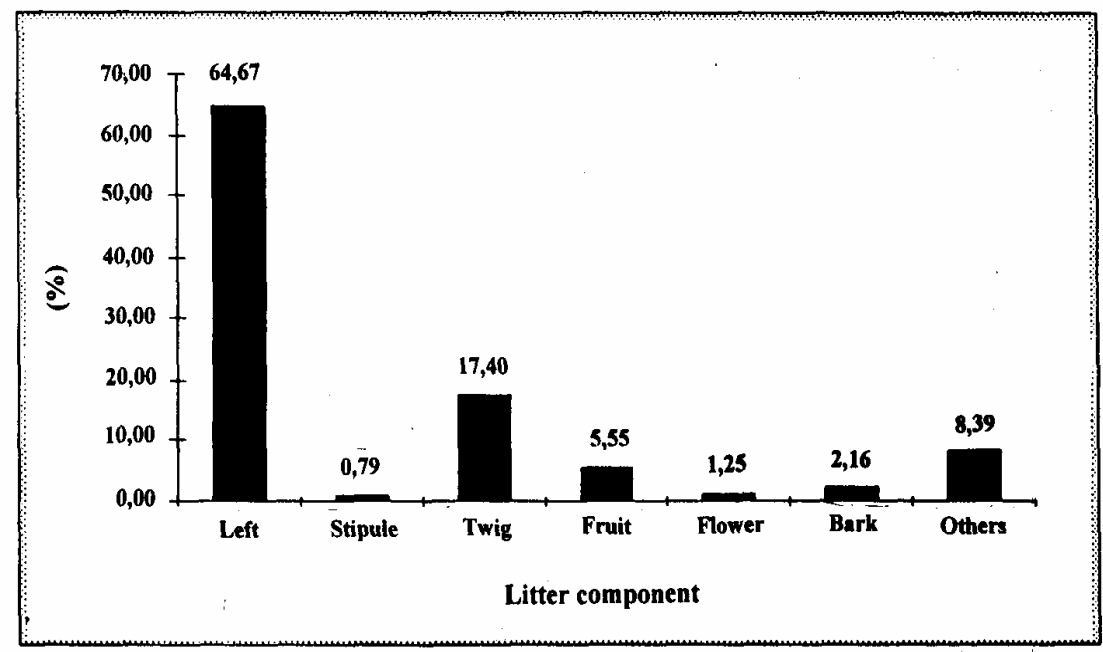

Figure 13. Percentage of litter component (average monthly dry weight) in a logged-over forest out in 1983/1984 


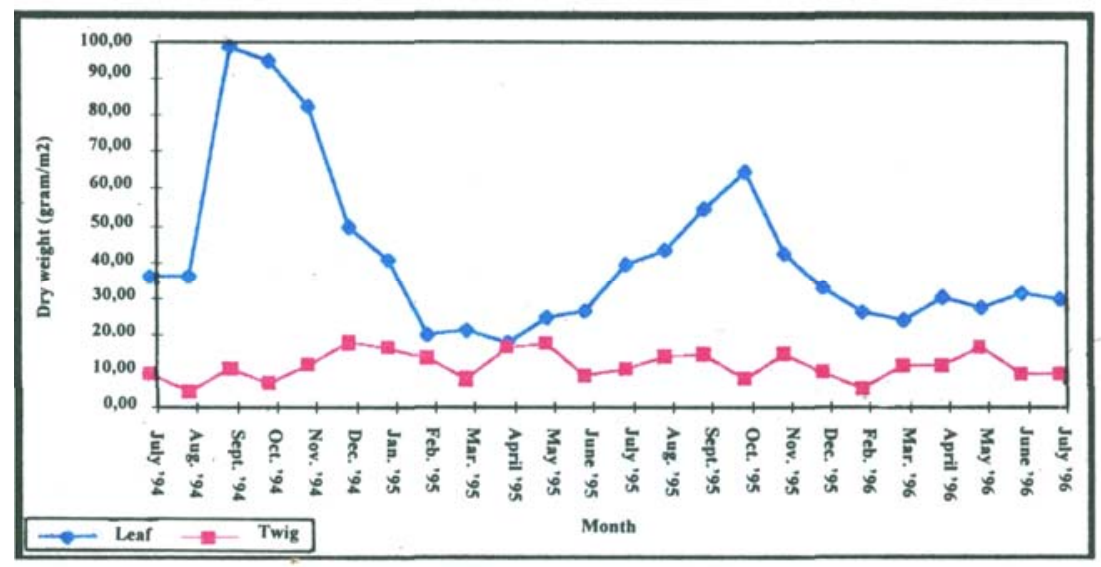

Figure 14. Leaf and twig litter production between July 1994 - July 1996 in the logged-over forest cut in 1979/1980

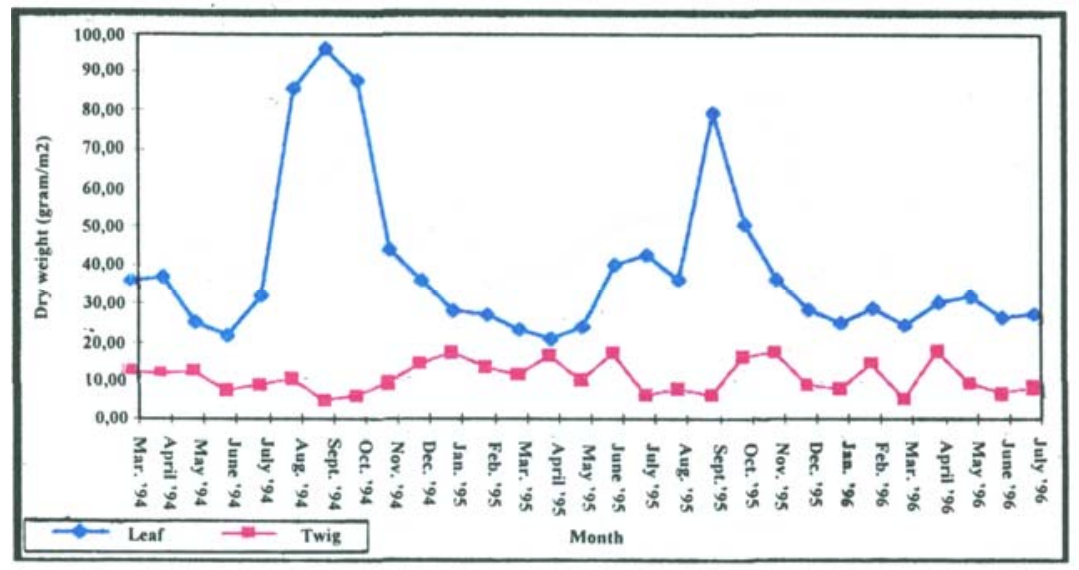

Figure 14. Leaf and twig litter production between March 1994 - July 1996 in the loggedover forest cut in 1983/1984 
Litterfall in a primary and two logged-over - Upik R. Wasrin \% Agus Eka Putra

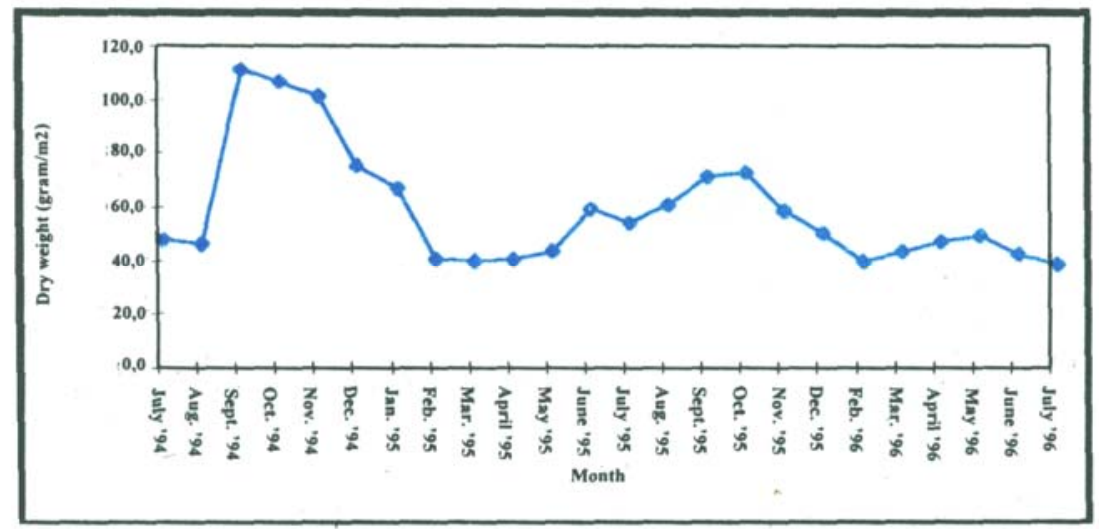

Figure 16. Total litter production between July 1994 - July 1996 in the logged-over forest out in $1979 / 1980$

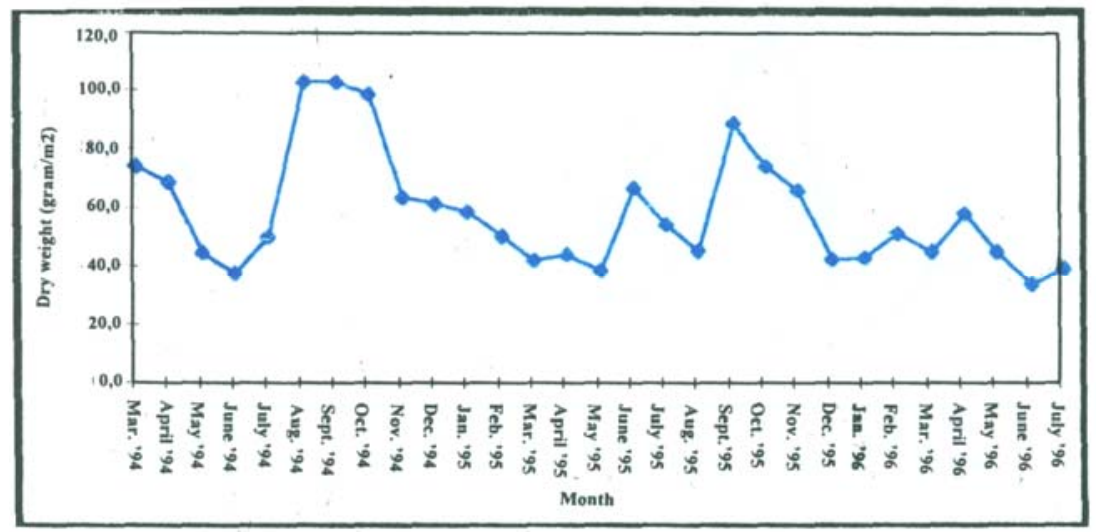

Figure 17. Total litter production between march 1994 - July 1996 in the logged-over forest 1983/1984 


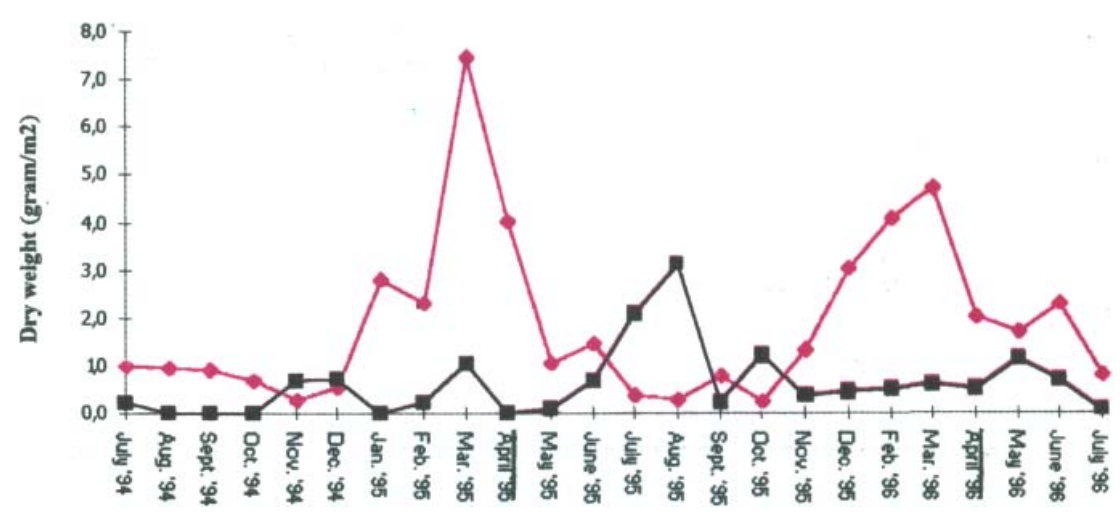

Figure 18. Fruit and flower litter production between July 1994 - July 1996 in the logged-over forest cut in 1979/1980.

relatively high production of fruit litter occurred in March 1995 and March 1996, whereas peak production of flower litter was recorded in August 1995 that might be responsible for the increase of fruit litter production in March 1996. Referring to the rainfall data in Fig. 9, highest flower litter production occurred in the months with the lowest monthly rainfall between October - December, while highest fruit litter production occurred in the months with the highest rainfall between January March or during the wettest months. There is a similarity with the primary forest. However, to observe the dynamics of fruit and flower litter production in more detail, longer period of observation of the logged-over forest is needed for at least the same period of observation as that for the primary forest.

In the logged-over forest cut in 19\&3/1984 the highest amounts of leaf litter were produced between August - October 1994 and in September 1995, while the lowest amounts were produced in June 1994, April 1995 and March 1996. The highest amounts of fruit litter were produced in March 1994, March 1995, and March 1996,.whereas the highest amounts of flower litter were produced in October 1994, July 1995 and November 1995. Fig. 19 also shows that the increased production of flower litter influences fruit litter production proportionally. 


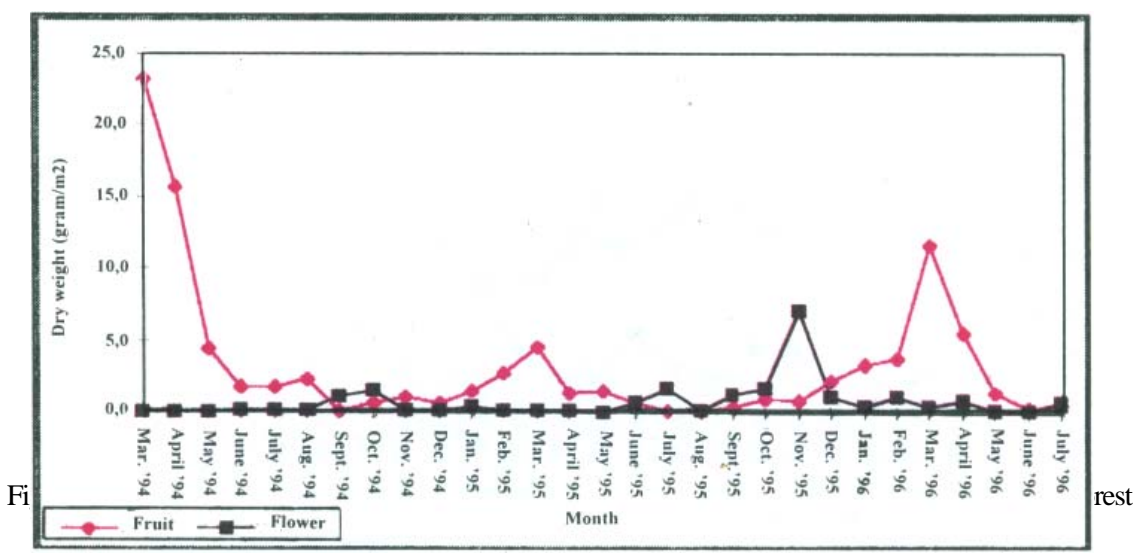

\section{ACKNOWLEDGMENTS}

This research is part of a joint research program between BIOTROP and Barito Pacific Timber Group (BPTG) at the Pasirmayang permanent plot, Jambi. The authors gratefully acknowledge Mr. Husin and Mr. Harmen and their staff at PT. IFA-BPTG for their assistance and support during the field work. We also wish to thank Mr. Musa for his assistance in the field and Mr. Waluyo for his assistance in the laboratory. Our sincere thanks are also due to Prof. Dr. Ralph Ockerse, Academic Advisor and Team Leader HEP-2 Yogyakarta, for his generous assistance in rewriting the manuscript.

\section{REFERENCES}

Alrasyid, H. 1986. Pelepasan unsur C organik dan unsur hara mineral lainnya selama pelapukan serasah di areal tegakan sisa hutan alam mangrove, sungai Sepada, Kalimantan barat. Buletin Penelitian Hutan 503 : 29-44.

Binkley, D. 1986. Forest Nutrition Management. A Wiley-lnterscience Publication. New York. 290 p. Ewel, J. 1983. Succession. In. Golley, F.B. (eds.). 1983. Ecosystem of the World 14A. Tropical Rain

Forest Ecosystems : Structure and Function. Elsevier Scientific Publishing Company. Amsterdam. 381 p.

Jordan, C.F. 1983. Productivity of Tropical Rain Forest Ecosystems and the Implications for Their Use As Future Wood and Energy Sources. In : Ecosystems of the World 14A.Tropical Rain Forest Ecosystems : Structure and Function. Elsevier Scientific Publishing Company. Amsterdam, p. $117-132$

Kira, T. \& T. Schidei. 1967. Primary Production and Turn Over of Organic Matter in Different ForestEcosystem. Ecology. Vol. 17, No. $3: 70$-87. 
Korcagin, A.A. 1960. Methods of Determination of the Seed Productivity of Forest Trees and Forest Communities. Field Geobotany II. Acad. of Science of the USSR Press.

Laumonier, Y. 1997. The Vegetation and Physiography of Sumatra. Geobotany 22. Kluwer Academic Publisher.

Medwecka-Komas. 1967. Ecosystem Studies in a Beech Forest and Meadow in the Ojcao National Park. In: Studia Nature. Ser. A

Medwecka-Kornas. 1970. Plant Litter Production. UNESCO.

Newbould, P.J. 1967. Methods for Estimating the Primary Production of Forests. IBP Handbook No. 2. Blackwell Scientific Publications. Oxford. 62 p.

Setyawan, T.P. 1999. Hubungan Produktivitas dan Laju Dekomposisi Serasah Pada Hutan Alam Primer dan Hutan Bekas Tebangan di Hutan Alam Produksi Pasirmayang, Jambi. Skripsi. Jurusan Manajemen Hutan, Fakultas Kehutanan, Institut Pertanian Bogor. Bogor. 67 p.

Wasrin, U.Rosalina, A. Eka Putra and I. Setiawan. 1995. Optimalisasi Produktivitas Lahan Hutan Alam Produksi di Areal Pengusahaan Hutan PT. IFA-Barito Pacific Timber Group, di Pasirmayang, Jambi. Laporan Penelitian. Kerjasama antara SEAMEO-BIOTROP dengan Barito Pacific Timber Bogor. $52 \mathrm{p}$. 